\title{
ОЦЕНКА ВОЗДЕЙСТВИЯ ПРЕПАРАТОВ НА ОСНОВЕ ВАCILLUS SUBTILIS И TRICHODERMA VIRIDE НА ФИТОСАНИТАРНУЮ СИТУАЦИЮ В ПОСЕВАХ И ПРОДУКТИВНОСТЬ ЯРОВОЙ ПШЕНИЦЫ В СЕВЕРНОЙ ЛЕСОСТЕПИ ЗАПАДНОЙ СИБИРИ
}

\author{
Бурлакова С.В., Егорычева М.T. \\ Сибирский федеральный научный центр агробиотехнологий Российской академии наук, \\ p.n. Краснообск, Россия, E-mail: burlackovasweta@yandex.ru
}

\begin{abstract}
The study was carried out in laboratory conditions and in the field experiment in the forest-steppe zone of Western Siberia. The protective effect of seed treatment with biofungicides Trichodermin and Sporobacterin in combination with spraying wheat crops with Fitosporin against root rot, the growth effect in the synergism of the biological properties of drugs was studied. It is shown that under the greening growth conditions of wheat, it is possible to replace the combination of chemical treatments with biological ones while maintaining a high level of productivity. The mechanism of influence of some combinations of drugs, revealing the peculiarities of biochemical processes in the cells of flag leaves of plants, on the forecast of productivity at the early stages of plant development has been revealed.
\end{abstract}

Keywords: Scarlet, Titul Duo, Trichodermin, Sporobacterin, fungicide compositions, spring wheat, biological efficiency, productivity.

\section{Введение}

В современных условиях при выращивании яровой пшеницы по различным технологиям акцент делается на экологизацию, снижение пестицидной нагрузки, повышение эффективности приемов контроля за фитосанитарной ситуацией. В настоящее время уделяется внимание разработкам микробиологического способа очистки почвы от пестицидов, применения препаратов на основе штаммовдеструкторов с полифункциональным действием [1].

Актуально применение таких препаратов, как триходермин, основу которого составляют грибы рода Trichoderma, споробактерин, состоящий из композиции Bacillus subtilis + Trichoderma viride. Новые штаммы микроорганизмов способны подавлять развитие патогенной микрофлоры, что в итоге снижает заболеваемость растений, повышает их продуктивность, улучшает качество растениеводческой продукции. Связано это с тем, что микроорганизмы хорошо приживаются в зоне корневой системы растений, усиливая свою активность. В результате значительно возрастает интенсивность микробиологических, биохимических и иных процессов в ризосфере, повышается растворимость труднодоступных элементов питания, накапливается 
биологический азот, повышается урожайность культур [2, 3]. Важным моментом, влияющим на качество и эффект обработки, является выбор препаративной формы таких препаратов, условия вегетационного периода. По данным литературы, по эффективности обработка семян Триходермином в форме порошка может уступать жидкой форме препарата в 2 раза. При варьировании степени развития корневой гнили от 5 до 8\%, то есть в пределах порога вредоносности, препарат снижал ее на 65-73\% в течение вегетации. Значительный результат можно получить путем сочетания обработки семян с обработками посевов как биологическими, так и химическими фунгицидами. По данным литературы, если обработка семян яровой пшеницы Триходермином (1л/т) обеспечивает прибавку 0,37 т/га, то ее сочетание с химическим фунгицидом по вегетации Байлетон $(0,5$ кг/га) - 0,6 т/га относительно контроля $(1,36$ т/га) [4]. Остается до конца неисследованным и на сегодняшний день актуальным изучение механизма метаболитических реакций растений при контакте с патогеном, в условиях абиотических стрессов при воздействии современных фунгицидов на основе штаммов микроорганизмов, проявление их низкой эффективности. Представляет большой интерес изучение возможности снижения пестицидной нагрузки на агроценоз путем сочетания химических фунгицидов с биофунгицидами и повышения биологической активности приемов применения [5].

\section{Материалы и методы}

Исследования проводили в 2019 г. в лабораторных условиях и на опытном поле СибНИИЗиХ СФНЦА РАН в ОПХ «Элитное» Новосибирского района Новосибирской области, почвенно-климатические условия которого типичны для лесостепной зоны Западной Сибири. Объекты исследований - яровая пшеница сорта Новосибирская 31; фунгицидные и микробные препараты. Проведена оценка эффективности предпосевной обработки семян яровой пшеницы препаратами Триходермин, П $(80$ г/T) и Споробактерин, СП (0,5 кг/т) и опрыскивания посевов Фитоспорином-М, П (0,4 кг/га, кущение+колошение) в сравнении с химическим протравителем Скарлет, МЭ (0,3 л/т) и фунгицидом Титул Дуо ККР (0,32 л/га, колошение) и контрольными вариантами (без обработки) для указанных приемов. Аммиачную селитру из расчета N60 вносили под предпосевную культивацию почвы. Площадь делянок по обработке семян 89,1 м², расположение последовательное в один ярус, повторность 3-х-кратная, по обработке посевов - 29,7 м², расположение методом расщепленных делянок. В опыте проводили учет развития обыкновенной корневой гнили [6], листовых инфекций [7], площади листьев [8], структуры урожая [9].

\section{Результаты и обсуждение}

Степень поражения посевов яровой пшеницы корневой гнилью не превышала ЭПВ с фазы 3,4 листьев до молочно-восковой спелости - 1,1\%; 2,8 и 9,6\% соответственно. Биологическая эффективность предпосевной обработки семян Споробактерином в фазу 3 листа составила 9,1\%, 4 листа - 39\%, а протравителем Скарлет - 45,0 и 60,7\% соответственно. Обработка семян Триходермином не снижала развития болезни в первую фазу учета, а во второй учет биологическая эффективность была $25,0 \%$. К фазе молочно-восковой спелости зерна пораженность растений корневой гнилью увеличилась, а показатели биологической эффективности снизились в варианте со Споробактерином до 20,8\%, со Скарлетом - до 32,3\%. В варианте протравливания семян Триходермином показатель развития болезни был на уровне контроля. 
Условия вегетационного периода года способствовали развитию аэрогенных инфекций. Уже в фазе начала колошения пшеницы пораженность растений септориозом составила 5,1 , мучнистой росой $-2,5 \%$, а к периоду молочной спелости зерна степень развития листовых болезней возросла до 14,2 и 10,8\%, соответственно. Учет развития листовых инфекций в фазе молочной спелости зерна показал, что обработка семян пшеницы препаратом Триходермин снизила развитие септориоза и бурой ржавчины на 55,6 и 26,2\%, Споробактерин - на 49,3\% и 31,1\% соответственно. На пораженность посевов мучнистой росой она оказала слабое влияние, биологическая эффективность биопрепаратов в этот период составила 2,8 и 5,5\%, соответственно. Обработка посевов Фитоспорином-М также оказала подавляющее действие лишь на пораженность растений септориозом, снизив его развитие на 53,5\%. При сочетании обработки посевов Фитоспорином-М с предпосевной обработкой семян биопрепаратами показатель биологической эффективности в фазе молочной спелости зерна варьировал по вариантам от 35,2 до 40,1\%, а с химическим протравителем он составил 59,9\%. Лучшие результаты в подавлении возбудителей септориоза в данный период развития растений были получены при использовании химического фунгицида Титул Дуо, как в чистом виде (биологическая эффективность $=70,4 \%$ ), так и в сочетании с биологическими протравителями семян - 70,4-72,5\% и с химическим эталоном Скарлет - 78,9\%. Максимальное подавление возбудителей бурой листовой ржавчины также наблюдалось при обработке посевов Титулом Дуо $(83,6 \%)$, в сочетании со Споробактерином $(83,6 \%)$ и Триходермином $(86,9 \%)$. Лучший результат $(96,7 \%)$ в борьбе с данной болезнью обеспечило применение протравителя Скарлет и фунгицида Титул Дуо.

Было отмечено положительное воздействие препаратов на формирование фотосинтетического аппарата. Рост листовых пластинок проявился при обработке семян Триходермином на $10 \%$, при ее сочетании с опрыскиванием посевов Фитоспорином-М - на 28\%, но более эффективным было ее сочетание с фунгицидом Титул Дуо - на 45\% относительно контроля (12,3 cм²/растение). Воздействие обработки семян Споробактерином как отдельно, так и в сочетании с Фитоспорином-М показало равнозначную стимуляцию - на $16 \%$, сочетание с эталонным фунгицидом также на $45 \%$, при этом обработка композицией химических эталонов стимулировала рост листовых пластинок в меньшей степени - на 39\%.

Исследование влияния биопрепаратов на формирование структуры урожая показало, что обработка семян в большей степени влияла на массу 1000 зерен, которая повышалась относительно контроля $(29,4$ г) на 3,8-7,4\%. Сочетание протравливания семян биологическими препаратами и обработки посевов фунгицидом Титул Дуо оказывало влияние как на структуру колоса, так и на массу 1000 зерен. Так, длина колоса увеличивалась на 11,2-21,9\%, количество колосков - на 8,4-19,4\%, количество зерен - на 35,4-63,9\%, масса зерна с колоса - на 47,5-81,2\%, масса 1000 зерен - на 14,3$18,3 \%$ относительно контроля.

В результате отмеченного воздействия препаратов урожайность повышалась относительно контроля $(2,09$ т/га) в вариантах по обработке семян: Триходермин, Споробактерин, Скарлет - на 0,18, 0,22 и 0,37 т/га; по обработке посевов: ФитоспоринM, Титул Дуо - на 0,09 и 0,47 т/га. Наибольшая прибавка была получена при сочетании препаратов Скарлет+Титул Дуо - на 1,0 т/га. В то же время необходимо отметить, что различия в урожайности, полученной в вариантах Споробактерин+Титул Дуо (0,8 т/га) и Скарлет+Титул Дуо, недостоверны, что позволяет сделать вывод о возможности 
снижения пестицидной нагрузки в агроценозах за счет введения в системы защиты растений микробиологических препаратов.

\section{Выводы}

1. Для обоснованного включения биологических препаратов в системы защиты растений проведена оценка эффективности предпосевной обработки семян яровой пшеницы препаратами Триходермин, П и Споробактерин, СП и опрыскивания посевов Фитоспори-ном-М, П в сравнении с химическим протравителем Скарлет, МЭ и фунгицидом Титул Дуо ККР. Выявлено, что обработка семян микробиологическими препаратами Триходер-мин и Споробактерин снижала пораженность растений корневой гнилью на 25 и 39\% и уступала химическому эталону Скарлет, эффективность которого составила $60 \%$. Предпосевная обработка семян биопрепаратами Триходермин и Споробактерин подавляла развитие септориоза в фазе молочной спелости зерна - на 55,6 и 49,3\%, соответственно, развитие бурой листовой ржавчины - на 26,2 и 31,1\%. Опрыскивание посевов фунгицидом Фитоспорин-М в фазы кущения и колошения пшеницы приводило к снижению развития только септориоза, подавляя его в фазе молочной спелости зерна на 53,5\%. Лучшие результаты по снижению пораженности растений пшеницы возбудителями септориоза и бурой листовой ржавчины были получены при использовании химического фунгицида Титул Дуо, как одного, так и в сочетании с биологическими препаратами и протравителем семян. Эффективность его в фазу молочной спелости зерна против септориоза составила 70,4-78,9\%, бурой листовой ржавчины - 83,6-96,7\%.

2. Обработка посевов химическим фунгицидом, также как и сочетание ее с обработкой семян биопрепаратами способствовала формированию мощного флагового листа пшеницы, увеличивая площадь листовой поверхности на 43,1-44,7\%.

3. В вариантах обработки семян достоверный рост урожайности пшеницы получен только при применении препарата Скарлет - на 0,37 т/га в сравнении с контролем $(2,09$ т/га). Обработка посевов микробиологическим фунгицидом Фитоспорин-М не влияла на урожайность. Использование химического фунгицида Титул Дуо для обработки посевов повысило сбор зерна на 0,47 т/га относительно контроля, при совмещении с обработкой семян Триходермином и Споробактерином - на 0,56 и 0,80 т/га соответственно, самая высокая урожайность была получена в варианте с применением двух химических препаратов, которая превысила контроль на 1,0 т/га. В то же время необходимо отметить, что различия в урожайности, полученной в вариантах Споробактерин+Титул Дуо и Скарлет+Титул Дуо, недостоверны, что позволяет сделать вывод о возможности снижения пестицидной нагрузки в агроценозах за счет введения в системы защиты растений биологических препаратов.

\section{Библиография}

1. Ксенофонтова О.Ю., Третьякова С.Э., Тихомирова Е.И., Васнецова Е.В. Разработка технологии использования биопрепарата для ремедиации почв, загрязненных пестицидом прометрин, в лабораторных и полевых условиях. - Известия Самарского научного центра РАН, 2016. №18 (2-3). С. 718-722.

2. Завалин, А.А. Оценка эффективности микробных препаратов в земледелии/ А.А. Завалин, Т.М. Духанина, М.В., Чистотин и др. М.: ВНИИА, 2000. 81 с.

3. Голованова Т.И., Долинская Е.В., Сичкарук Е.А. Взаимоотношения почвенного гриба Trichoderma и яровой пшеницы. Вестник Красноярского ГАУ, 2009. №7. С. 102-107. 
4. Замятин С.А. Сравнительная эффективность биологических и химических препаратов в борьбе с болезнями яровой пшеницы: дисс. канд. с.-х. наук. Чувашский НИИСХ. Йошкар-Ола, 2000. 16 с.

5. Сафин С.С., Таланов И., Садриев А. Как защитить растения в условиях ресурсосберегающих технологий. 2014. [Электронный ресурс]. URL: http://agroobzor.ru/ahim/a-114.html.

6. Торопова Е.Ю., Кириченко А.А. Фитосанитарный экологический мониторинг. Методические указания к лабораторно-практическим занятиям и контрольной работе. Новосибирск. НГАУ. - 2012. - 38 с.

7. Санин С.С., Пыжикова Г.В. Практические рекомендации по диагностике, учету и защите пшеницы от бурой ржавчины, септориоза и мучнистой росы. М.: Колос, 1988. $26 \mathrm{c}$.

8. Радионов А.И., Василько В.П., Цаценко Л.В. Выполнение и оформление выпускных квалификационных работ: метод. Рекомендации для студентов-бакалавров и магистрантов. - Краснодар: КубГАУ, 2016. - 63 с.

9. Методика государственного сортоиспытания сельскохозяйственных культур (вып.2), зерновые, зернобобовые, кукуруза и кормовые культуры М., 1989, 194 с. 